\title{
Research Scholarly Productivity of Universities: From the Perspective of Knowledge Transfer
}

\author{
Wei'e Wu \\ College of Zhijiang, Zhejiang University of Technology, Hangzhou, Zhejiang, P. R. China \\ E-mail: wwe@zju.edu.cn
}

\begin{abstract}
Knowledge transfer acts as essential mediator to build research scholarly productivity of university faculty. However, the effects that knowledge transfer takes on research scholarly productivity of universities are still quite ambiguous, which results in ignorance of procedural concern about how knowledge transfer promotes research scholarly productivity through interaction and synergy between university faculty and specific knowledge users (receivers). Therefore, we proposed a conceptual model and 13 hypotheses, which illustrate the elements influencing knowledge transfer while university faculty engage in research work and make contribution to research scholarly productivity. Later, correlation and regression analysis were done to verify the model and hypotheses, and the statistical results indicate: the processes of "conduct research work" (knowledge transmit) and "absorb research outcome" (knowledge accept) pose the first and second greatest total effects on research scholarly productivity, which implies university faculty should pay high attention to the procedural management while making research; "communication environment" takes the third place to influence research scholarly productivity, which suggests building proper communication environment for knowledge transmission by university faculty and absorption by specific knowledge receivers is indirectly important to the level of research scholarly productivity; the last but not the least, an unexpected finding that "knowledge characteristics" (complexity) does exert direct effect on research scholarly productivity, which probably reveals university faculty is eager to grasp open opportunities and difficult challenges- the more complex the knowledge, the stronger willing to undertake research and transfer knowledge.
\end{abstract}

Keywords-knowledge transfer; research scholarly productivity; universities; correlation and regression analysis; total effect

\section{INTRODUCTION}

Universities (academia) take an important role in Triple Helix model as novelty production (knowledge), while industry engages in wealth generation (market) and government responses for public control (regulation) (Loet Leydesdorff, Martin Meyer, 2006). In comparison with teaching scholarship, research scholarly productivity of universities hold more interactive involvements with economic growth and commercialization in terms of outputs (Teresa R Behrens, Denis O Gray, 2001; Agrawal, 2006; Markus Perkmann, Kathryn Walsh, 2007). It's found positive synergistic effects of the interaction between university and government, industrial $R \& D$ in regions with high entrepreneurial activity (Younghwan Kim, WonjoonKim,
Taeyoung Yang, 2012). These suggest that universities should possess great capability of research productivity in the way of knowledge transfer. The available literature mostly takes total number of publications to measure research productivity (Ted D. Englebrecht, Timothy Bisping, Mary M. Anderson, James R. Hasselback, 2008; James R. Hasselback, Alan Reinstein, Philip M.J. Reckers, 2011; John H. Kranzler, Sally L. Grapin, Matt L. Daley, 2011), and engages in determinants of research productivity including age, sex, scientific disciplines, professional status, reputation of university, laboratory size, quality of colleagues, funding and so on (Nicolas Carayol, Mireille Matt, 2006). However, the research productivity of university doesn't restrict to article publication, and actually encompasses more besides publication works, projects committed, tasks consignation, collaboration, patents, software, graduate programs, and basic initiative research.

Meanwhile, knowledge transfer acts as essential mediator to build research scholarly productivity of university faculty. Relative literature put focuses on: university technology transfer patterns such as patent authorization, collaborative research, commercial spin-offs (Siegel, Waldman, Atwater, 2003; Landry ,Amara, Rherrad, 2006); process and content of university-industry- government collaboration, and factors hindering technology transfer (Elias G Carayannis, Jeffrey Alexander, Anthony Ioannidis, 2000; Meyer-Krahmer, Schmoch, 1998; Li Wengbo, 2003); economic effects and institution of university technology transfer (Siegel, Waldman, 2003). Anyway, the literature didn't directly refer to "knowledge transfer" though technology transfer inevitably holds intensive relevance with it, didn't concentrate on micro analysis of how knowledge transfer takes effects on research scholarly productivity of universities.

Therefore, the following questions represent our specific interests: What are the important determinants of research scholarly productivity of university from the perspective of knowledge transfer? How important are the interaction and synergy between universities and specific knowledge users?

\section{CONCEPTUAL MODEL AND HYPOTHESES}

In general, knowledge transfer means knowledge flow from the sender to receiver, and covers two key processes of transmission and absorption (see Fig.1). From the orientation of knowledge flow, knowledge transfer mainly involves the following elements: 1) knowledge sender who initiates the procedure of knowledge transfer, 2) receiver who accepts the transmitted knowledge, 3) the knowledge that is the object handled, 4) media and ways by which knowledge flow and 
transfer are implemented. Moreover, external environment exerts influences on knowledge transfer too, such as physical,

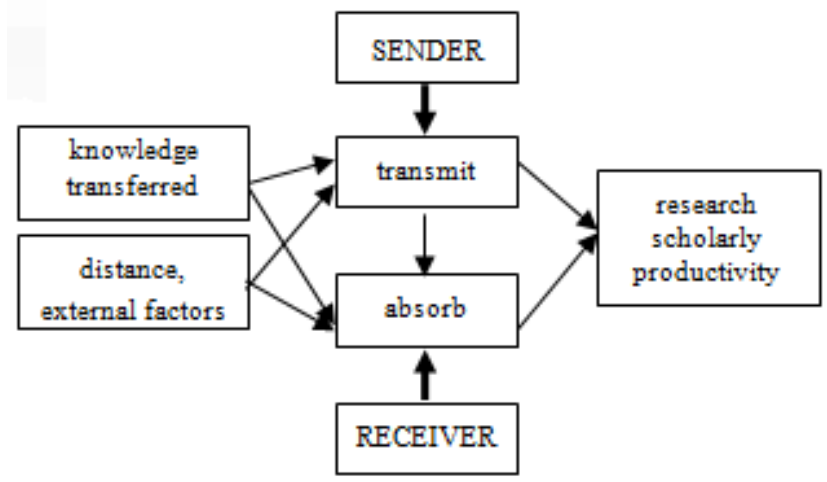

Figure.1. knowledge transfer

From the view of knowledge transfer, research scholarly productivity of universities here defines as capability to achieve knowledge creation and knowledge increment through research activities for relative stakeholders. It means not only competency for knowledge production (static outcomes), but also for academic course (dynamic process). University faculty and professional research staff act as knowledge senders, who attain knowledge advantages through research scholarly activities, while other parties outside of universities (industry, government, scholars) are eager for such knowledge, thus transfer of academic knowledge from university to outside is urged between these different parties. The knowledge receivers probably involve collaboration parties, publication readers, research work occupiers, project consigners and any party who absorbs knowledge outcomes from university research activities. So, university research activities imply fundamental elements of knowledge transfer: knowledge, sender, receiver, interaction between the knowledge transferee and the transferred.

Therefore, university research scholarly productivity implies the capability to make knowledge contribution and achieve knowledge increment for the relative participants through scholarly research activities, and the extent of thus capability as well as its explicit performance is mainly determined by two important processes: knowledge creation /research work, and absorption of knowledge outcome. Meanwhile, those two processes are greatly influenced by knowledge characteristics (e.g., complexity), knowledge distance and disparities between the transferee and transferred participants, communication and interactive environment, interaction activities, research capability of the knowledge transferee, and so on. Based on discussion of the relevant literature and findings of past studies, a conceptual model for research scholarly productivity of universities is proposed (see Fig.2), from the perspective of knowledge transfer, and 13 hypotheses are suggested:

H1: Complexity of knowledge has a negative effect on research activities, i.e. academic process, of the knowledge senders (mainly research faculty in universities). cultural, institutional and technological environmental factors.

$\mathrm{H} 2$ : Complexity of knowledge has a negative effect on research outcomes absorption of the knowledge receivers.

H3: The higher capability to conduct research activities, the better performance the research faculty in universities have, the easier goes the research process.

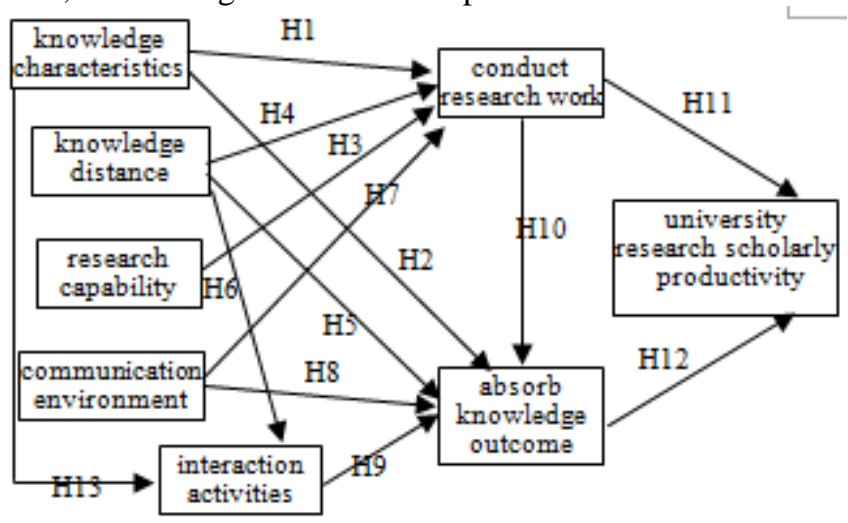

Figure.2. Conceptual model

H4: Knowledge distance and disparities between relative participants or parties of university research activities influence the process of research conduction and knowledge transmission.

H5: Knowledge distance and disparities between relative participants or parties of university research activities influence the process of absorption of knowledge outcomes by the research receivers.

H6: The narrower knowledge distance between relative participants or parties of university research activities, or the more similar knowledge background they have, the more smoothly and easily interaction between them goes.

H7: The better interactive environment and communication, more helpfully promote the research faculty in universities to carry on the research activities and ensure the proper research progress.

H8: The better interactive environment and communication, more helpful to absorb knowledge outcomes from the relative research activities by the knowledge receivers.

H9: The smoother and better the interactions between the knowledge sender and receiver through research scholarly activities (i.e. relative participants or parties of university research activities), the better effect of knowledge absorption.

H10: Research work or knowledge transmission process executed by the research faculty in universities has a positive effect on knowledge absorption by research outcome users/receivers.

H11: Research work or knowledge transmission process executed by the research faculty has a positive effect on research scholarly productivity of university.

H12: Absorption of knowledge outcome/ research production has a positive effect on research scholarly productivity of universities. 
H13: Complexity of knowledge has an influence on interaction between relative participants or parties of university research activities.

\section{DATA AND METHODOLOGY}

In this study individual faculty members were the unit of data analysis. First, a questionnaire about the elements (variables) proposed in the above conceptual model (see Fig.2) was designed and sent to sample faculty. Six items were proposed to measure the variable "knowledge characteristics (mainly about complexity)", nine items for the variable "research capability", three for "knowledge distance", seven for "communication environment", five for "interaction activities", ten for the process "conduct research work", five for the process "absorb research outcomes", and seven for "research scholarly productivity". Survey participants were asked to rate the measuring items of each variables according to their own research experience, and ratings were given on a 5 -point scale representing different levels: $1=$ totally disagree, $2=$ not agree, $3=$ generally agree, $4=$ agree, $5=$ highly agree .

The sample included 103 full-time faculty, mostly affiliated to seven universities (Zhejiang University, Fudan University, Shanghai Jiaotong University, Nankai University, Harbin University of Technology, Donghua University, and Tsinghua University, etc.). 94 questionnaires were completed satisfactorily for a weighted valid response rate of $91.3 \%$, and 67 were done by the male teachers and 27 by the female. $58.5 \%$ of them work in the domain of natural science and other $41.5 \%$ in the domain of social science; 49 teachers are titled as professor (52.13\%), 22 as lecture (23.40\%) and 23 as associate professor $(24.47 \%)$.

Second, statistical analysis was made to confirm the rationality of each element (variable) and construct validity. While screening out right measuring items and achieving right quality of the items, some tests were made: Corrected-Item Total Correlation (CITC, demanded to be higher than 0.5), Cronbach's $\alpha$ coefficient $(\geq 0.7)$, single dimensionality by factor analysis (demanding factor load coefficient more than 0.5 ) to ensure strong reliability, convergent and discrimination validity. The statistical results (after the measuring items were corrected, and CITC $\geq 0.5$ ) were listed in TABLE I.

Later, Correlation analysis and Regression (OLS) were taken to reveal the important determinants of research scholarly productivity of university from the perspective of knowledge transfer, and explore the effect of these determinants exerted on the research scholarly productivity. Considering the length of paper, the complete statistic processes were omitted here. The correlation coefficients were shown as follows (see TABLE II).

It was found from TABLE II as follows:

a) the variable "research scholarly productivity" has positive correlativity with other seven variables with significance $\mathrm{p}<0.01$ except the significance level related to "knowledge distance" $(0.01<\mathrm{p}<0.05)$;

b) the two process of knowledge transfer: conduct research work and absorb research outcomes, hold highest correlativity, respectively 0.56 and 0.58 - which can provide preliminary confirmation of theoretical hypotheses $\mathrm{H} 11$ and $\mathrm{H} 12$; and

c) the correlation coefficients (Pearson) between "research scholarly productivity", "conduct research work", "absorb research outcomes" and the other five variables, reveal the corresponding variables involved in hypotheses $\mathrm{H} 1 \sim \mathrm{H} 13$ does exist have correlativity.

In order to explore and determine the statistical relationship between the influential factors (of knowledge transfer) and the procedural and sequential variables (of university scholarly research), we made Regression analysis (OLS): respectively took "conduct research work", "absorb research outcomes" and "research scholarly productivity" as dependent variables, chose corresponding elements as independent variables according to the conceptual model (see Fig. 2) and 13 hypotheses proposed, and then made regression analysis (Stepwise). The results were shown as follows (see TABLE III).

According to the statistical results listed in TABLE III, we can find:

a) The hypotheses of $\mathrm{H} 3, \mathrm{H} 4$ and $\mathrm{H} 7, \mathrm{H} 9$ and $\mathrm{H} 10, \mathrm{H} 11$ and $\mathrm{H} 12$ have been supported; while $\mathrm{H} 1, \mathrm{H} 2, \mathrm{H} 5$ and $\mathrm{H} 8$ haven't been verified statistically.

b) An unexpected result that "knowledge complexity" takes a direct effect on "research scholarly productivity", here we name it $\mathrm{H} 14$.

Thus, we can put forward the regression model for research scholarly productivity of universities from the perspective of knowledge transfer (see Fig. 3).

Later, we calculated the direct, indirect and total effects that relative variables put on research scholarly productivity of universities (see TABLE IV).

As for the process of "conduct research work", communication environment plays greatest direct effect on it (0.535, see TABLE IV), and research capability does second greatest influence $(0.320)$. That may suggests university faculty need essential conditions and atmosphere for proper communication and cooperation when they engage in research work. 
TABLE I. RELIABILITY AND CONVERGENT VALIDITY OF VARIABLES

\begin{tabular}{|c|c|c|c|c|c|c|}
\hline Variables & $\begin{array}{l}\text { Number of Items } \\
\text { (adjusted) }\end{array}$ & Cronbach $\alpha$ & $\begin{array}{c}\text { Kaiser-Meyer-Olkin } \\
\text { (KMO })\end{array}$ & $R^{2}$ & Bartlett $\chi^{2}$ & Sig. \\
\hline $\begin{array}{c}\text { knowledge } \\
\text { characteristics }\end{array}$ & 5 & .7236 & .655 & $48.873 \%$ & 113.551 & .000 \\
\hline research capability & 9 & .890 & .908 & $56.380 \%$ & 374.274 & .000 \\
\hline knowledge distance & 2 & .628 & .538 & $73.109 \%$ & 21.988 & .000 \\
\hline $\begin{array}{c}\text { communication } \\
\text { environment }\end{array}$ & 6 & .861 & .845 & $59.680 \%$ & 243.066 & .000 \\
\hline interaction activities & 5 & .839 & .828 & $61.371 \%$ & 180.874 & .000 \\
\hline conduct research work & 10 & .917 & .909 & $57.440 \%$ & 547.523 & .000 \\
\hline $\begin{array}{c}\text { absorb research } \\
\text { outcomes }\end{array}$ & 4 & .732 & .702 & $56.525 \%$ & 87.049 & .000 \\
\hline $\begin{array}{l}\text { research scholarly } \\
\text { productivity }\end{array}$ & 7 & .885 & .876 & $59.472 \%$ & 315.347 & .000 \\
\hline
\end{tabular}

TABLE II. Correlations between the Measured Variables (Pearson)

\begin{tabular}{|c|c|c|c|c|c|c|c|c|}
\hline Variables & $\begin{array}{c}\text { knowledge } \\
\text { characteristics }\end{array}$ & $\begin{array}{c}\text { research/ } \\
\text { transfer } \\
\text { capability }\end{array}$ & $\begin{array}{l}\text { knowledge } \\
\text { distance }\end{array}$ & $\begin{array}{c}\text { communication } \\
\text { environment }\end{array}$ & $\begin{array}{l}\text { conduct } \\
\text { research } \\
\text { work }\end{array}$ & $\begin{array}{c}\text { interaction } \\
\text { activities }\end{array}$ & $\begin{array}{c}\text { absorb } \\
\text { research } \\
\text { outcomes }\end{array}$ & $\begin{array}{c}\text { research } \\
\text { scholarly } \\
\text { productivity }\end{array}$ \\
\hline $\begin{array}{c}\text { knowledge } \\
\text { characteristics }\end{array}$ & 1.00 & & & & & & & \\
\hline $\begin{array}{c}\text { research/transfer } \\
\text { capability }\end{array}$ & $0.31 * * *$ & 1.00 & & & & & & \\
\hline knowledge distance & 0.16 & $0.24 * * *$ & 1.00 & & & & & \\
\hline $\begin{array}{c}\text { communication } \\
\text { environment }\end{array}$ & $0.37 * * *$ & $0.48 * * *$ & $0.28 * * *$ & 1.00 & & & & \\
\hline conduct research work & $0.38 * * *$ & $0.62 * * *$ & $0.40 * * *$ & $0.74 * * *$ & 1.00 & & & \\
\hline interaction activities & $0.30 * * *$ & 0.17 & $0.33 * * *$ & $0.32 * * *$ & $0.36 * * *$ & 1.00 & & \\
\hline $\begin{array}{c}\text { absorb research } \\
\text { outcomes }\end{array}$ & $0.31 * * *$ & $0.41 * * *$ & $0.41 * * *$ & $0.37 * * *$ & $0.58 * * *$ & $0.40 * * *$ & 1.00 & \\
\hline $\begin{array}{l}\text { research scholarly } \\
\text { productivity }\end{array}$ & $0.37 * * *$ & $0.46^{* * *}$ & $0.25^{* *}$ & $0.37 * * *$ & $0.56^{* * *}$ & $0.27 * * *$ & $0.58 * * *$ & 1.00 \\
\hline
\end{tabular}

$* * *$ Correlation is significant at the 0.01 level (2-tailed), $\mathrm{p}<0.01 ; * *$ Correlation is significant at the 0.05 level (2-tailed), $\mathrm{p}<0.05$

TABLE III. Regression Analysis (Stepwise)

\begin{tabular}{|c|c|c|c|c|c|c|c|c|c|c|}
\hline \multirow{2}{*}{$\begin{array}{l}\text { Dependent } \\
\text { variables }\end{array}$} & \multirow[t]{2}{*}{ Independent } & \multirow{2}{*}{$\begin{array}{c}\text { Unstandardized } \\
\text { Coefficients }\end{array}$} & \multirow{2}{*}{$\begin{array}{l}\text { Standardized } \\
\text { Coefficients }\end{array}$} & \multirow[t]{2}{*}{$t$} & \multirow[t]{2}{*}{ Sig. } & \multicolumn{2}{|c|}{$\begin{array}{c}\text { multicollinearity } \\
\text { Diagnosis }\end{array}$} & \multirow[t]{2}{*}{$F$} & \multirow[t]{2}{*}{$R^{2}$} & \multirow{2}{*}{$R^{2}$} \\
\hline & & & & & & Tol. & VIF & & & \\
\hline \multirow{4}{*}{$\begin{array}{l}\text { (1) } \\
\text { conduct } \\
\text { research } \\
\text { work }\end{array}$} & (constant) & 0.253 & & 0.820 & 0.414 & & & \multirow{4}{*}{58.30} & \multirow{4}{*}{0.66} & \multirow{4}{*}{0.65} \\
\hline & $\begin{array}{l}\text { research } \\
\text { capability }\end{array}$ & 0.343 & 0.320 & 4.540 & 0.000 & 0.761 & 1.314 & & & \\
\hline & $\begin{array}{l}\text { communication } \\
\text { environment }\end{array}$ & 0.451 & 0.535 & 7.509 & 0.000 & 0.743 & 1.346 & & & \\
\hline & $\begin{array}{c}\text { knowledge } \\
\text { distance }\end{array}$ & 0.164 & 0.173 & 2.680 & 0.009 & 0.907 & 1.103 & & & \\
\hline \multirow{3}{*}{$\begin{array}{c}(2) \\
\text { absorb } \\
\text { research } \\
\text { outcomes }\end{array}$} & (constant) & 1.378 & & 4.238 & 0.000 & & & \multirow{3}{*}{27.73} & \multirow{3}{*}{0.38} & \multirow{3}{*}{0.37} \\
\hline & $\begin{array}{c}\text { conduct research } \\
\text { work }\end{array}$ & 0.484 & 0.499 & 5.637 & 0.000 & 0.871 & 1.149 & & & \\
\hline & $\begin{array}{l}\text { Interaction } \\
\text { activities }\end{array}$ & 0.144 & 0.223 & 2.514 & 0.014 & 0.871 & 1.149 & & & \\
\hline
\end{tabular}


TABLE III. Regression Analysis (Stepwise)(continued)

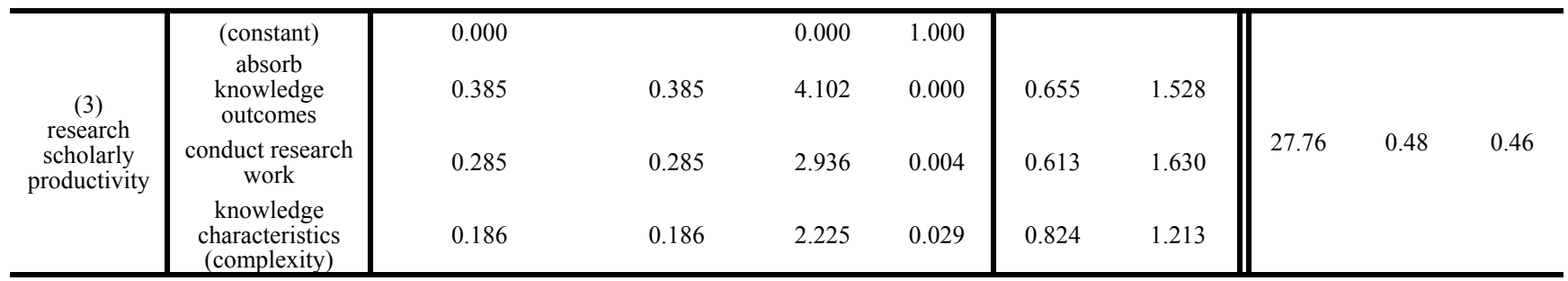

Note: $p<0.05$. Tol. is abbreviation of tolerance, VIF is shorted for variance inflated factor. In general, if tolerance $(0.6 \sim 1)$ is more approaching 1 and VIF far less than 10 , there is no or weak multicollinearity.

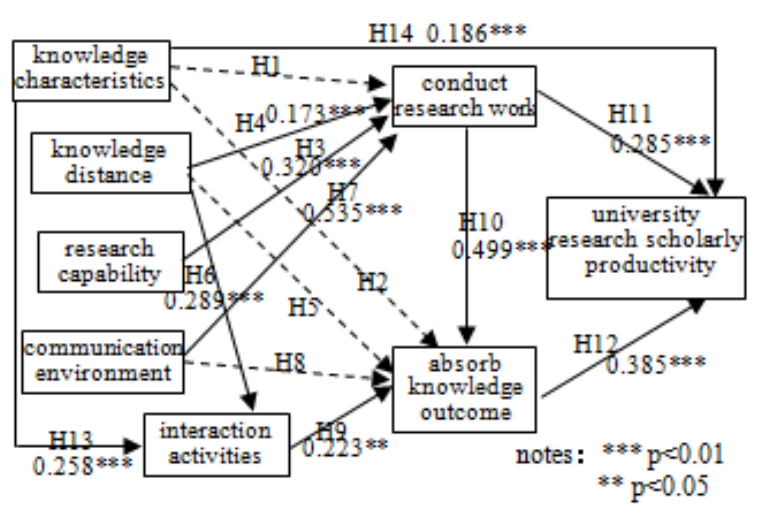

Figure.3. Regression model for research scholarly productivity of universities

As for the process of "absorb research outcomes", direct influences are exerted by the process of "conduct research work" (0.499) and "interaction activities" (0.223), while indirect effects are put by "knowledge distance" $(0.151)$ and "knowledge characteristics" (0.058). It's obviously faculty's research process plays the most important part for others to absorb knowledge from research outcomes.

As for "research scholarly productivity", 1 variable (the process of "absorb research outcomes") exerts direct effect on it, 4 variables put indirect effects, and 2 variables take both direct and indirect effects. In view of direct effect, the process of "absorb research outcomes" $(0.385)$ contributes most to "research scholarly productivity", which probably implies knowledge contribution deriving from faculty's research requires more of the receivers' assimilation and endeavors rather than the senders' engagement.

TABLE IV Direct, Indirect and Total effects

\begin{tabular}{|c|c|c|c|c|}
\hline $\begin{array}{l}\text { Dependent } \\
\text { Variable }\end{array}$ & $\begin{array}{l}\text { Relative } \\
\text { Variables }\end{array}$ & $\begin{array}{l}\text { Direct } \\
\text { Effect }\end{array}$ & $\begin{array}{l}\text { Indirect } \\
\text { Effect }\end{array}$ & $\begin{array}{l}\text { Total } \\
\text { Effect }\end{array}$ \\
\hline \multirow{3}{*}{$\begin{array}{l}\text { conduct } \\
\text { research } \\
\text { work } \\
\text { (transmit } \\
\text { knowledge) }\end{array}$} & $\begin{array}{l}\text { research } \\
\text { capability }\end{array}$ & 0.320 & 0.000 & 0.320 \\
\hline & $\begin{array}{l}\text { knowledge } \\
\text { distance }\end{array}$ & 0.173 & 0.000 & 0.173 \\
\hline & $\begin{array}{l}\text { communication } \\
\text { environment }\end{array}$ & 0.535 & 0.000 & 0.535 \\
\hline
\end{tabular}

\begin{tabular}{|c|c|c|c|c|}
\hline \multirow{4}{*}{$\begin{array}{c}\text { absorb } \\
\text { research } \\
\text { outcome } \\
\text { (accept } \\
\text { knowledge) }\end{array}$} & $\begin{array}{c}\text { conduct } \\
\text { research work }\end{array}$ & 0.499 & 0.000 & 0.499 \\
\hline & $\begin{array}{l}\text { interaction } \\
\text { activities }\end{array}$ & 0.223 & 0.000 & 0.223 \\
\hline & $\begin{array}{l}\text { knowledge } \\
\text { characteristic } \\
\text { (complexity) }\end{array}$ & 0.000 & 0.058 & 0.058 \\
\hline & $\begin{array}{l}\text { knowledge } \\
\text { distance }\end{array}$ & 0.000 & 0.151 & 0.151 \\
\hline \multirow{7}{*}{$\begin{array}{c}\text { research } \\
\text { scholarly } \\
\text { productivity } \\
\text { of } \\
\text { universities }\end{array}$} & $\begin{array}{l}\text { knowledge } \\
\text { characteristic } \\
\text { (complexity) }\end{array}$ & 0.186 & 0.022 & 0.208 \\
\hline & $\begin{array}{c}\text { conduct } \\
\text { research work }\end{array}$ & 0.285 & 0.192 & 0.477 \\
\hline & $\begin{array}{c}\text { absorb research } \\
\text { outcome }\end{array}$ & 0.385 & 0.000 & 0.385 \\
\hline & $\begin{array}{l}\text { research } \\
\text { capability }\end{array}$ & 0.000 & 0.153 & 0.153 \\
\hline & $\begin{array}{c}\text { communication } \\
\text { environment }\end{array}$ & 0.000 & 0.345 & 0.345 \\
\hline & $\begin{array}{l}\text { interaction } \\
\text { activities }\end{array}$ & 0.000 & 0.086 & 0.086 \\
\hline & $\begin{array}{l}\text { knowledge } \\
\text { distance }\end{array}$ & 0.000 & 0.025 & 0.025 \\
\hline
\end{tabular}

From the view of total effect, the process of "conduct research work" (0.477) has the first greatest influence on "research scholarly productivity" and $23.9 \%$ greater than the process of "absorb research outcomes" $(0.385$, ranked the second greatest) has. Hence, it can be inferred that successful knowledge transfer through research scholarship requires dedication of relative participants, especially the knowledge sender and receiver.

Meanwhile, it is worthy of notice that, though "knowledge characteristics (complexity)" doesn't pose direct effect on the process of either "conduct research work" or "absorb research outcomes", it does exert direct influence on "research scholarly productivity" (with direct effect 0.186 and total effect 0.208). This is an unexpected finding, and the probably explanation is: the more complex and implicit the 
knowledge is, the more difficult to achieve and the more demand for such knowledge, so that arise more opportunities for cooperation and consignation of research programs, which eventually implemented through university faculty's endeavors and transfer of knowledge outcomes, and hence the research scholarly productivity of universities are improved. It probably can be presumed that cooperation or consignation of research programs mainly are determined by the extent how the knowledge supply and demand match.

\section{CONCLUSIONS}

Hence, we can arrive at following findings:

Finding 1: Nine hypotheses are supported by statistical results except $\mathrm{H} 1, \mathrm{H} 2, \mathrm{H} 5$ and $\mathrm{H} 8$ (see Fig.3). An exploratory outcome (H14) is unexpectedly attained: complexity of knowledge poses a positive effect on research productivity of universities. This might be due to the university faculty's preference to challenges.

Finding 2: Considering total effects put on variables "conduct research work", "absorb research outcome", and "research scholarly productivity", we discover:

(1) "Research capability", "knowledge distance" and "communication environment" exert direct effect on the process of "conduct research work", and "communication environment" exhibits the greatest positive influence, which may imply the faculty need excellent communication atmosphere to tap out research capability.

(2) "Knowledge distance", "knowledge characteristics /complexity", "communication environment" and the process of "conduct research work" have direct or indirect influence on "absorption of knowledge outcome", and "conduct research work" process puts the largest effect. This requires research performance and its process should be given emphasis so that to stimulate effectiveness of knowledge transfer.

(3) Three variables "conduct research work" process, "absorb research outcome" and "knowledge characteristics (complexity)", exert direct and positive influences on "research scholarly productivity", and other four variables give indirect effects. However, "conduct research work" and "absorb research outcome" hold the first and second greatest total effect, from which it can be inferred high research productivity need right cooperation of relative parties, that is to say, university research faculty (knowledge sender) and research outcome absorber (knowledge receiver), with right match of knowledge supply and demand.

Meanwhile, university faculty usually is eager to grasp open opportunities and difficult challenges: the more complex the knowledge, the stronger willing to transfer it.

\section{ACKNOWLEDGMENT}

The author gratefully acknowledges the support of National Science Fund of Zhejiang Province, P.R. China (No. LY13G030028).

\section{REFERENCES}

[1] Agrawal, A. "Engaging the inventor: exploring licensing strategies for university inventions and the role of latent knowledge". Strategic Management Journal, 2006, 27 (1): 63-79.

[2] Elias G Carayannis, Jeffrey Alexander, Anthony Ioannidis. "Leveraging knowledge, learning, and innovation in forming strategic government-university-industry (GUI) R\&D partnerships in the US, Germany, and France". Technovation, 2000, 20(9): 477-488.

[3] John H. Kranzler, Sally L. Grapin, Matt L. Daley. "Research productivity and scholarly impact of APA- accredited school psychology programs: 2005-2009". Journal of School Psychology, 2011, 49(6): 721-738

[4] James R. Hasselback, Alan Reinstein, Philip M.J. Reckers. "A longitudinal study of the research productivity of graduates of accounting doctoral programs". Advances in International Accounting, 2011 (27):10-16.

[5] Landry, R., Amara, N., Rherrad, I.. "Why are some university researchers more likely to create spin-offs than others? Evidence from Canadian universities ". Research Policy, 2006, 35: 1599-1615.

[6] Loet Leydesdorff, Martin Meyer. "Triple Helix indicators of knowledge-based innovation systems: Introduction to the special issue". Research Policy, 2006, 35: 1441-1449.

[7] Markus Perkmann, Kathryn Walsh. "Engaging the scholar: Three types of academic consulting and their impact on universities and industry". Research Policy, 2008, 37(10): 1884-1891.

[8] Meyer-Krahmer, F. \& Schmoch, U. "Science-based technologies: university- industry interactions in four fields". Research Policy, 1998, 27: 835-851.

[9] Nicolas Carayol, Mireille Matt. "Individual and collective determinants of academic scientists' productivity". Information Economics and Policy, 2006, 18(1): 55-72.

[10] Siegel, D.S., Waldman, D. A. \& Atwater, L.E. et al. "Commercial knowledge transfers from universities to firms: improving the effectiveness of university- industry collaboration". Journal of High Technology Management Research, 2003, 14: 111-133.

[11] Ted D. Englebrecht, Timothy Bisping, Mary M. Anderson, James R. Hasselback. "A further inquiry into the scholarly productivity of academic accountants: Twenty years of evidence from classes of 1980-82". Advances in Accounting, 2008, 24(1): 24-31.

[12] Teresa R Behrens, Denis O Gray. "Unintended consequences of cooperative research: impact of industry sponsorship on climate for academic freedom and other graduate student outcome". Research Policy, 2001, 30(2): 179-199.

[13] Younghwan Kim, Wonjoon Kim, Taeyoung Yang. "The effect of the triple helix system and habitat on regional entrepreneurship: Empirical evidence from the U.S.". Research Policy, 2012, 41: 154-166. 